STUDIA PRAWNO-EKONOMICZNE, t. CV, 2017

PL ISSN 0081-6841; e-ISSN 2450-8179 s. 365-380

DOI: $10.26485 / \mathrm{SPE} / 2017 / 105 / 20$

Irena PYKA*

Aleksandra NOCOŃ**

\title{
KONCEPCJA I GŁÓWNE ZAŁOŻENIA EXIT STRATEGY Z PERSPEKTYWY DOŚWIADCZEŃ CENTRALNEGO BANKU JAPONII
}

\begin{abstract}
(Streszczenie)
Exit strategy to koncepcja wyjścia z globalnego kryzysu finansowego powstała wskutek woli politycznej państw G-20 wyrażonej w dokumentach Izby (Rady) Stabilności Finansowej (Financial Stability Board). Oznacza ona powrót do „normalnej” polityki monetarnej, a zatem tej z okresu przed globalnym kryzysem finansowym. Jednakże banki centralne, które zastosowały nadzwyczajną politykę pieniężną, nie potrafią z niej wyjść, pomimo licznych deklaracji jej normalizacji. Niestabilna sytuacja makroekonomiczna gospodarki japońskiej po globalnym kryzysie finansowym spowodowała zainteresowanie warunkami wyjścia z nadzwyczajnej polityki monetarnej Banku Japonii. Bank ten posiada bowiem bogate doświadczenia zarówno w jej upowszechnianiu, jak też normalizacji. Tuż przed globalnym kryzysem finansowym Bank Japonii rozpoczął normalizację swej nadzwyczajnej polityki monetarnej, podjętej w latach 90-tych XX w., ponownie stając przed koniecznością powrotu do niej.

Głównym celem opracowania jest wskazanie i weryfikacja cech koncepcji exit strategy banku centralnego Japonii ukierunkowanych na zwiększenie skuteczności i bezpieczeństwa procesu normalizacji polityki monetarnej banków centralnych po globalnym kryzysie finansowym. W artykule wykorzystano następujące metody badawcze: studium przypadku (case study), analizę obserwacji, analizę przyczynowo-skutkową, analizę dokumentów oraz analizę syntezy.
\end{abstract}

Słowa kluczowe: strategia wyjścia; Bank Japonii; luzowanie ilościowe; polityka zerowych stóp procentowych; normalizacja polityki pieniężnej

Klasyfikacja JEL: E52, E58, E43

* Prof. zw. dr hab., Uniwersytet Ekonomiczny w Katowicach, Katedra Bankowości i Rynków Finansowych; e-mail: irena.pyka@ue.katowice.pl

** Dr, Uniwersytet Ekonomiczny w Katowicach, Katedra Bankowości i Rynków Finansowych; e-mail: aleksandra.nocon@ue.katowice.pl 


\section{Wstęp}

Exit strategy to koncepcja związana z powrotem do „normalnej” polityki monetarnej, zakładająca wycofanie się banków centralnych z nadzwyczajnych jej instrumentów, stosowanych w okresie globalnego kryzysu finansowego. Potrzeba realizacji exit strategy wyrażona została w dokumentach Rady Stabilności Finansowej (Financial Stability Board) ${ }^{1}$. W perspektywie założeń oznacza skupienie się banków centralnych na kilku prostych operacjach, służących zapewnieniu stabilności cen wspierającej prowzrostową politykę gospodarczą państwa. W praktyce jednak, niepewność co do perspektyw poziomu aktywności gospodarczej, stopy inflacji czy też funkcjonowania mechanizmu transmisji impulsów monetarnych mogą komplikować realizację strategii wyjścia. Dowodzi tego sytuacja, jaka wytworzyła się po globalnym kryzysie finansowym. Banki centralne, które zastosowały nadzwyczajną politykę pieniężną, nie potrafią z niej wyjść pomimo licznych deklaracji normalizacji polityki monetarnej. FED o zakończeniu realizacji programów zakupu aktywów zdecydował pod koniec 2013 r., chociaż w czerwcu 2011 r. Federalny Komitet Otwartego Rynku (Federal Open Market Committee - FOMC) opublikował tzw. „Zasady strategii wyjścia” (Exit Strategy Principles $)^{2}$. Natomiast podwyżkę stóp procentowych wprowadził warunkowo dopiero w 2015 r. EBC z kolei tkwi w nadzwyczajnej polityce monetarnej, realizując kolejne programy skupu papierów wartościowych i politykę niskich stóp procentowych. Jednocześnie Bank Anglii (Bank of England) pierwsze komunikaty dotyczące ewentualnego wdrożenia strategii wyjścia formułował już w roku $2010^{3}$. Do normalizacji polityki monetarnej podchodzi jednak z dużą ostrożnością, kierując się stanem dynamiki wzrostu gospodarczego i oczekiwań rynków finansowych.

Niepewna sytuacja w zakresie realizacji exit strategy po globalnym kryzysie finansowym spowodowała zainteresowanie warunkami wyjścia z nadzwyczajnej polityki monetarnej Banku Japonii. Posiada on bowiem bogate doświadczenia zarówno w jej upowszechnianiu, jak też normalizacji. Bank Japonii niestandardowe instrumenty polityki monetarnej zastosował na początku lat 90-tych XX w., kiedy to gospodarka Japonii borykała się po okresie swego dynamicznego roz-

Financial Stability Board, Exit from extraordinary financial sector support measures, Note for G20 Ministers and Governors meeting 6-7 November 2009.

2 http://www.federalreserve.gov/monetarypolicy/files/fomcminutes20110622.pdf; stan na 11.08.2014 r.

3 J. Bank, Monetary Policy - Exit Strategy, Macroeconomic Research Jyske Markets, 23 March 2010, s. 7. 
woju z poważnymi problemami recesji i deflacji gospodarczej. Krótko przed globalnym kryzysem finansowym rozpoczął normalizację swej nadzwyczajnej polityki monetarnej, ponownie stając przed koniecznością powrotu do niej. Głównym celem opracowania jest wskazanie i weryfikacja cech koncepcji exit strategy banku centralnego Japonii ukierunkowanych na zwiększenie skuteczności i bezpieczeństwa procesu normalizacji polityki monetarnej banków centralnych po globalnym kryzysie finansowym.

\section{Analiza celów, instrumentów i konsekwencji nadzwyczajnej polityki monetarnej Banku Japonii w latach 2001-2006}

Bank centralny Japonii stanął przed problemem wykorzystania niestandardowych instrumentów polityki monetarnej na początku nowego stulecia. Ostatnia dekada XX w. okazała się bowiem w gospodarce Japonii wyjątkowo trudna. Kraj ten borykał się z poważnym kryzysem sfery realnej gospodarki, bardzo niskim (okresami nawet ujemnym) wzrostem gospodarczym oraz deflacją. Wzrost aktywności gospodarczej i przejście do bezpiecznego poziomu inflacji Bank Japonii wspierał realizacją nadzwyczajnej polityki monetarnej.

19 marca 2001 r. zdecydował o zmianie nastawienia polityki pieniężnej w zakresie ${ }^{4}$ :

1) celu operacyjnej polityki pieniężnej,

2) doboru instrumentów polityki pieniężnej,

3) zobowiązania do utrzymywania dodatniego tempa wzrostu stopy inflacji w ujęciu rok do roku.

Modyfikacja celu polityki pieniężnej polegała na przejściu Banku Japonii z kontroli poziomu podstawowej stopy procentowej (overnight uncollateralized call rate) na kontrolę wielkości poziomu rezerw utrzymywanych przez banki na rachunku bieżącym w banku centralnym (Current Account Balances - CAB). Suma rezerw wymaganych i nadwyżkowych jako nowy cel operacyjny Banku Japonii docelowo ustalona została na poziomie 5 bln JPY (o 1 bln JPY więcej niż stanowiła średnia wielkość rezerw w lutym 2001 r.). Suma tych rezerw Banku Japonii (Bank of Japan - BoJ) stale jednak rosła, osiagając w styczniu 2004 r.

4 A. van Rixtel, The exit from Quantitative Easing (QE): The Japanese experience, w: Symposium Report, Armonk, New York, 23-25 października 2009 r., s. 262; http://www.law.harvard.edu/ programs/about/pifs/symposia/japan/2009-japan/final-report/2009-japan-u.s.-symposium-finalreport.pdf; stan na 11.06.2015 r. 
poziom 35 bln JPY (por. tabela 1). Oznaczało to, że pomimo silnej determinacji Banku Japonii w kreowaniu podaży pieniądza bankowego zmiana celu operacyjnego polityki pieniężnej nie była wystarczająco skutecznym jego działaniem proinflacyjnym. W tym czasie Bank Japonii podjął bowiem zobowiązanie, że będzie zaopatrywał sektor bankowy w płynność, dopóki inflacja nie ustabilizuje się na poziomie bliskim $0 \%$ lub nie zacznie wzrastać, co wynikało z akceptacji zmiany nastawienia polityki monetarnej i przyjęcia obowiązku utrzymywania dodatniego tempa wzrostu stopy inflacji w ujęciu rok do roku.

TABELA 1: Docelowy poziom rezerw utrzymywanych przez banki komercyjne na rachunku w Banku Japonii

\begin{tabular}{|c|c|}
\hline Data podjęcia decyzji przez Bank Japonii & Docelowy poziom rezerw (w mld JPY) \\
\hline 16.03 .2001 & 600 \\
\hline 14.08 .2001 & 6000 \\
\hline 18.09 .2001 & Powyżej 6000 \\
\hline 19.12 .2001 & $10000-15000$ \\
\hline 30.10 .2002 & $15000-20000$ \\
\hline 01.04 .2003 & $17000-22000$ \\
\hline 30.04 .2003 & $22000-27000$ \\
\hline 20.05 .2003 & $27000-30000$ \\
\hline 10.10 .2003 & $27000-32000$ \\
\hline 20.01 .2004 & $30000-35000$ \\
\hline
\end{tabular}

Ź r ó dło: opracowanie własne na podstawie danych Banku Japonii.

Podstawowym instrumentem polityki monetarnej Banku Japonii w $2001 \mathrm{r}$. stało się natomiast zwiększanie skali prowadzonych bezwarunkowych operacji otwartego rynku (outright purchase), w których główny przedmiot transakcji stanowiły zakupy długoterminowych obligacji rządowych (Japanese Government Bonds - JGB) - do 400 mld JPY miesięcznie. W styczniu 2002 r. zakres nabywanych papierów wartościowych w ramach operacji outright purchase rozszerzono o obligacje 10- i 20-letnie, jak również o krótszych terminach zapadalności (2-, 4-, 5- oraz 6-letnie). W listopadzie 2002 r. ponownie zwiększona została skala dokonywanych zakupów papierów wartościowych do 1,2 bln JPY miesięcznie ${ }^{5}$.

5 S. P. Berkmen, Bank of Japan's Quantitative and Credit Easing: Are They Nom More Effective, IMF Working Paper 2012/WP/12/2, Washington, s. 3. 
Ważnym instrumentem polityki monetarnej lat 2001-2007 Banku Japonii były także bezwarunkowe zakupy bonów emitowanych przez banki zabezpieczone aktywami akceptowanymi przez bank centralny ${ }^{6}$ (por. wykres 1$)^{7}$. Ich wartość w portfelu BoJ w marcu 2001 r. wynosiła 11,4 bln JPY, a w marcu 2006 r. aż 37,8 bln JPY. Rekordową wartość tych krótkoterminowych papierów wartościowych odnotowano w styczniu 2006 r. na poziomie 44,2 bln JPY ${ }^{8}$. Należy też podkreślić, że tempo wzrostu wartości nabywanych bonów było kilkukrotnie wyższe niż rządowych papierów wartościowych w okresie realizacji nadzwyczajnej polityki monetarnej (polityki Quantitative Easing - luzowania ilościowego) (wykres 1)9. Świadczy to o roli, jaką transakcje zakupu bonów odgrywały $\mathrm{w}$ przeprowadzanych operacjach rynku pieniężnego i w realizacji nowej polityki pieniężnej Banku Japonii. Nie tylko bowiem udział, ale i współczynnik korelacji pomiędzy zmianami wielkości bonów komercyjnych i rezerw bankowych BoJ był wysoki. Pomiędzy marcem 2001 r. a marcem 2006 r. wskaźnik ten mierzony rok do roku wynosił $30 \%$. Wykorzystanie bonów przez BoJ było także powodowane ich znaczną elastycznością w oddziaływaniu na płynność banków w reakcji na krótkoterminowe wahania czynników autonomicznych oraz wysoką atrakcyjność przeprowadzanych operacji.

Analizowane instrumenty nowej polityki monetarnej BoJ nie były jednak wystarczająco skuteczne, aby zwiększyć zainteresowanie banków akcją kredytową i podnieść wskaźnik inflacji w Japonii. Bank Japonii z tego powodu dopuścił również do transakcji otwartego rynku papiery wartościowe o dłuższym terminie zapadalności - do roku, rozszerzył listę podmiotów, które mogły w nich uczestniczyć, jak również zwiększył listę aktywów kwalifikowanych jako ich zabezpieczenie. Zastosował też, kierując się założonym celem polityki monetarnej, operacje otwartego rynku, których przedmiotem były zakupy papierów wartościowych zabezpieczonych aktywami (Asset-Backed Securities - ABS), zarówno krótkoterminowe (Asset-Backed Commercial Papers - ABCP), jak i długoterminowe (Longer-term-ABS).

6 W ramach aktywów akceptowanych jako zabezpieczenie przeprowadzanych operacji znalazły się instrumenty emitowane przez podmioty zarówno sektora publicznego, jak i prywatnego, w tym: obligacje korporacyjne, bony komercyjne oraz pozostałe instrumenty dłużne.

7 Bank of Japan, Money market operations in Fiscal 2003, Financial Markets Department, August 2004 oraz E. Maeda, B. Fujiwara, A. Mineshima, K. Taniguchi, Japan's open market operations under the Quantitative Easing policy, Bank of Japan Working Paper Series 2005/05-E-3.

8 A. van Rixtel, op. cit., s. 263.

9 Ibidem. 
WYKRES 1: Zmiany wielkości bonów oraz japońskich skarbowych papierów wartościowych w bilansie Banku Japonii w latach 2000-2009

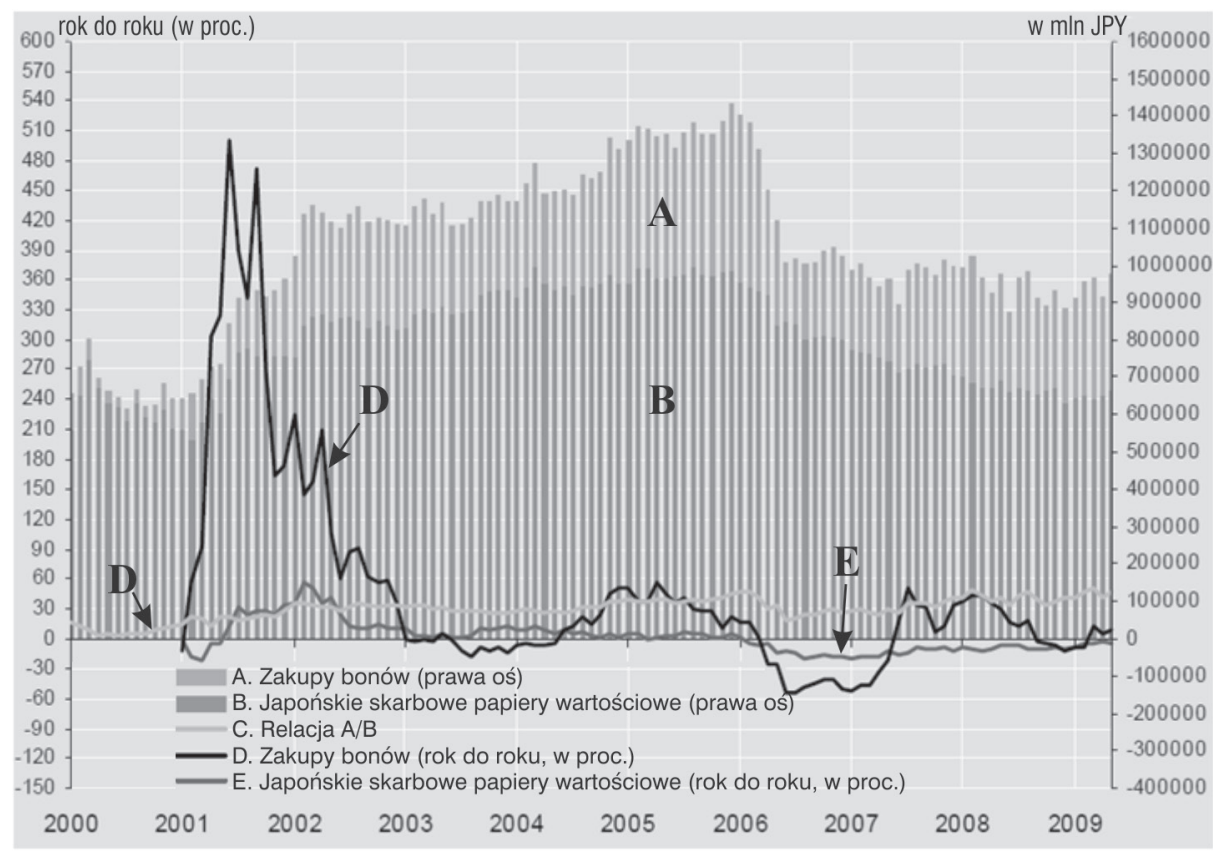

Źró dło: A. van Rixtel, The exit from Quantitative Easing (QE): The Japanese experience, w: Symposium Report, Armonk, New York, 23-25 October 2009 r., s. 262; http://www.law.harvard. edu/programs/about /pifs/symposia/japan/2009-japan/final-report/2009-japan-u.s.-symposium-final-report.pdf; stan na 11.06.2015 r.

Realizując nową politykę monetarną, przeprowadzał także bezpośrednie zakupy akcji. Pojawiły się one w aktywach centralnego Banku Japonii pod koniec 2002 r. BoJ nabywał akcje od instytucji finansowych za pośrednictwem banku powierniczego (trust bank), które w jego bilansie określane zostały jako pecuniary trust (por. wykres 2).

Polityka monetarna Banku Japonii oparta na nowych zasadach w latach 2001-2006 spowodowała istotne przemiany w wielkości i strukturze jego bilansu. Po stronie aktywów nastapił wzrost wielkości nabywanych japońskich rządowych papierów wartościowych (w tym obligacji i krótkoterminowych bonów skarbowych). W marcu 2001 r. ich poziom wyniósł 57,7 bln JPY i wzrósł do 93,3 bln JPY w marcu 2006 r. Bardzo wysoki był współczynnik korelacji pomiędzy zmianami wielkości skarbowych papierów wartościowych w aktywach 
banku centralnego w ujęciu rok do roku a zmianami wartości rezerw bankowych mierzonych także w ujęciu rok do roku w okresie marzec 2001 r. - marzec 2006 r. (na poziomie $82 \%)^{10}$, wskazując, że polityka luzowania ilościowego Japonii realizowana z wykorzystaniem tych instrumentów okazała się skuteczna.

WYKRES 2: Zmiany wybranych pozycji aktywów Banku Japonii w latach 2000-2009

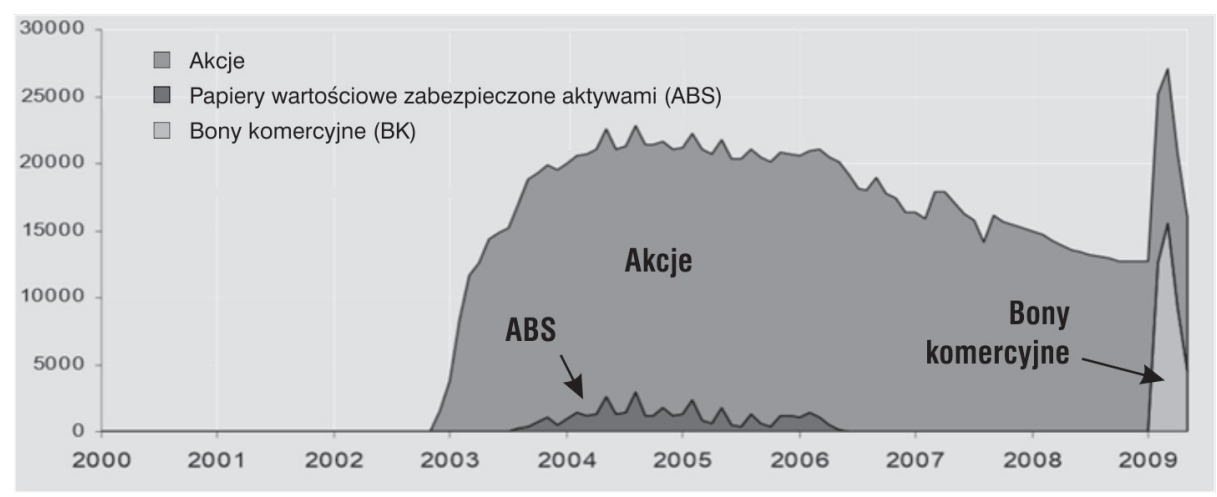

Źródło: A. van Rixtel, op. cit., s. 263.

Walka ze spiralą deflacyjną w Japonii podjęta została również w obszarze zmian stopy procentowej. Bank Japonii od stycznia 2001 r. do lipca 2006 r. utrzymywał podstawową stopę procentową na poziomie $0 \%$ (wykres 3 ). Polityka zerowych stóp procentowych tego okresu miała stymulować japońską gospodarkę oraz doprowadzić do spłaszczenia krzywej dochodowości ${ }^{11}$. Wyniki przeprowadzonych badań empirycznych wskazują, iż ta polityka BoJ była skuteczna ${ }^{12}$. Trudno natomiast ocenić, w jakim stopniu spadek krótko- i średnioterminowych stóp procentowych był determinowany zakupami skarbowych papierów wartościowych przez bank centralny Japonii, a w jakim utrzymywaniem stopy procentowej na zerowym poziomie.

10 A. van Rixtel, op. cit., s. 262.

11 A.S. Blinder, Quantitative Easing: Entrance and Exit Strategies, Federal Reserve Bank of St. Louis Review, November/December 2010/92 (6), s. 475.

12 H. Ugai, Effects of the Quantitative Easing Policy: A Survey of the Empirical Evidence, Bank of Japan Working Paper, July 2006/06-E-10. 
WYKRES 3: Zmiany poziomu podstawowej stopy procentowej Banku Japonii (Uncollateraized overnight call rate) w okresie wrzesien 1998 - marzec 2006

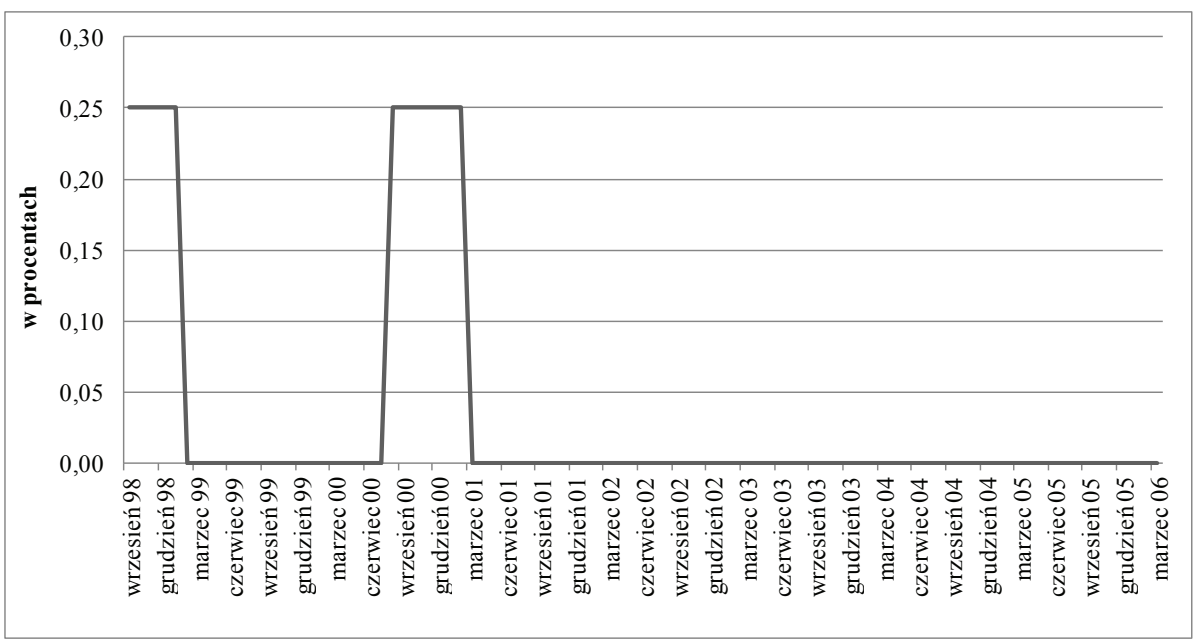

Ź r ó d ło: opracowanie własne na podstawie danych Banku Japonii.

\section{Założenia strategii wyjścia Banku Japonii}

Bank Japonii, korzystając z niestandardowych instrumentów w realizacji nowej polityki monetarnej po roku 2001, jednocześnie pierwszy określił założenia strategii wyjścia (exit strategy). Ogłoszone 9 marca 2006 r. zasady normalizacji polityki pieniężnej Banku Japonii zakładały, że obniżka nadwyżkowych rezerw w systemie bankowym Japonii zostanie dokonana poprzez operacje płynnościowe, a nie szybką redukcję portfela japońskich skarbowych papierów wartościowych. BoJ obawiał się bowiem, iż nagła odsprzedaż obligacji państwowych spowoduje obniżenie ich ceny, a tym samym inwestorzy poniosą dotkliwe straty z tytułu ich niskiej wyceny ${ }^{13}$. Bank Japonii zdecydował się więc na mocno uporządkowane i stopniowe wychodzenie z nadzwyczajnej polityki monetarnej, kontynuując regularne zakupy papierów wartościowych przy zachowaniu dotychczasowej ich wartości (1,2 bln JPY) oraz częstotliwości, zakładając równocześnie spadek portfela rządowych papierów wartościowych w bilansie banku centralnego na skutek wygaśnięcia ich terminów zapadalności.

13 S. Goldman, Quantitative Easing: The final chapter, Japan Economics Analyst, 3 marca 2006; S. Goldman, BoJ terminates quantitative easing policy: Nominal tightening, but real easing, Japan Economic Flash, 9 March 2006. 
Podobną politykę prowadził względem obniżki udziału krótkoterminowych papierów wartościowych w swym portfelu aktywów. Wykorzystując papiery te w krótkoterminowych operacjach otwartego rynku pieniężnego, stopniowo kończył rolowanie kapitału w wyniku wygaszania terminów zapadalności tych instrumentów. Ponieważ średni czas zapadalności krótkoterminowych bonów komercyjnych wynosił 4 miesiące, zakładano, iż w marcu 2006 r. większości z nich upłynie termin wymagalności w lecie $2006 \mathrm{r} .{ }^{14}$ Potwierdziły te przewidywania dane bilansu Banku Japonii. W 2005 r. udział tych papierów wartościowych w portfelu jego aktywów wynosił 51\% i zmniejszył się do 50\% w 2006 r., a w 2007 r. do 47\% ${ }^{15}$.

W konsekwencji realizacji założeń strategii wyjścia suma bilansowa Banku Japonii w ciagu kilku miesięcy w roku 2006 spadła do poziomu 8 bln JPY, podczas gdy w trakcie dwóch i pół roku realizacji nowej polityki monetarnej wzrosła z poziomu 5 bln JPY do około 33 bln JPY (wykres 4).

WYKRES 4: Zmiany wielkości aktywów oraz rezerw nadmiernych w trakcie luzowania ilościowego w Japonii w latach 1998-2012

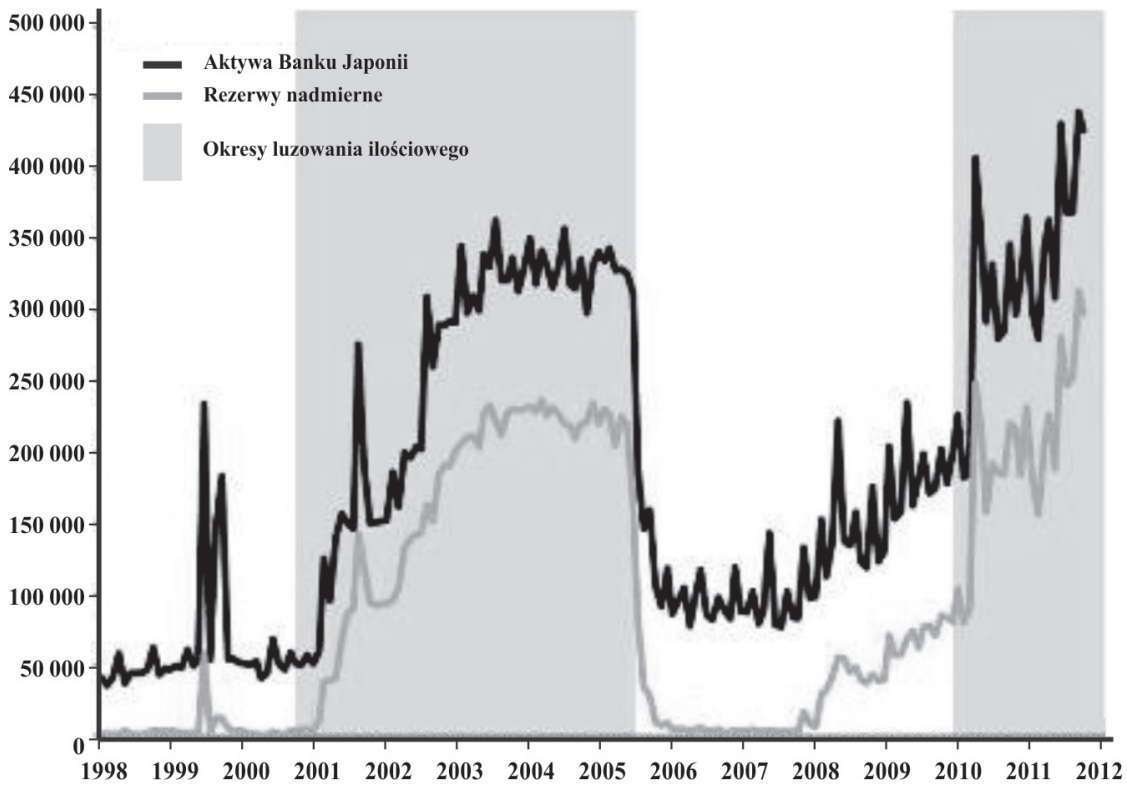

Ź ró d ło: http://www.marketminder.com/a/fisher-investments-shinzo-abes-unstimulatingstimulus/7dbad7e4-4d0a-47bf-962c-714100ffc3e8.aspx; stan na 16.06.2015 r.

14 Bank of Japan, Money market operations in Fiscal 2006, Financial Markets Department, July 2007, s. 7.

15 A. van Rixtel, op. cit., s. 266. 
Nastąpiło także zmniejszenie wielkości rezerw w bilansie banku centralnego z 145 bln JPY w marcu 2006 r. do 116 bln JPY w lipcu 2006 r. Spadek ten w znacznym stopniu wynikał ze zmniejszenia o 20 bln JPY operacji zasilających rynku pieniężnego oraz finansowania banków komercyjnych w banku centralnym ${ }^{16}$.

Bank Japonii zakończył też realizację programów zakupu aktywów ABS i ABCP bez konieczności dokonywania ich odsprzedaży ze względu na ${ }^{17}$ :

a) klauzule wygaśnięcia (sunset clauses) - kiedy rozpoczęto wykup papierów wartościowych, określono, iż termin ich zapadalności wygaśnie w marcu 2006 r. W rezultacie uczestnicy rynku dokładnie znali czas zakończenia programów, bez konieczności dalszego informowania przez bank centralny o etapach realizacji strategii wyjścia.

b) relatywnie krótki okres zapadalności nabytych papierów wartościowych - w 2006 r., kiedy gospodarka japońska powróciła na ścieżkę wzrostu, udział instrumentów ABS był nieznaczny (ok. 1 mld JPY).

Na początku 2006 r. Bank Japonii zdecydował też o odejściu od polityki zerowej stopy procentowej, podnosząc jej poziom po raz pierwszy od ponad pięciu lat z $0 \%$ do $0,25 \%$, uznając, że zagrożenie deflacją minęło (wykres 5$)^{18}$.

Bank Japonii w 2006 r. zdecydował się więc zakończyć politykę zerowych stóp procentowych. Wzrost stóp procentowych stał się jednym z najistotniejszych aspektów strategii wyjścia Banku Japonii. Przed podniesieniem stóp procentowych Bank Japonii musiał jednak uprzedzić oczekiwania uczestników rynku. Wyjście z polityki niskich stóp procentowych mogło bowiem spowodować drastyczne zmiany w krzywej dochodowości osłabiające rysujące się ożywienie gospodarcze. Zgodnie z wcześniejszymi komunikatami uczestnicy rynku spodziewali się bowiem zerowych stóp procentowych w długim okresie czasu. Bank Japonii w strategii wyjścia określił więc niezbędne warunki początku podwyżki stóp procentowych. Uznał, że wskaźnik inflacji CPI (Consumer Price Index) powinien osiagnąć poziom co najmniej $0 \%$ lub powyżej w ciagu kilku kolejnych miesięcy, a prognozy inflacji bazowej powinny ukształtować się na poziomie powyżej $0 \% \mathrm{w}$ okresie prognozy.

16 H. Yamaoka, M. Syed, Managing the Exit: Lessons from Japan's Reversal of Unconventional Monetary Policy, IMF Working Paper, May 2010/WP/10/114, s. 7.

17 Ibidem, s. 9.

18 K. Nishizaki, T. Sekine, Y. Ueno, Chronic Deflation in Japan, Bank of Japan Working Paper 2012/12-E-6, Bank of Japan, Tokyo, s. 12-18. 
WYKRES 5: Zmiany poziomu podstawowej stopy procentowej Banku Japonii (Uncollateraized overnight call rate) w okresie kwiecień 2006 - grudzień 2016

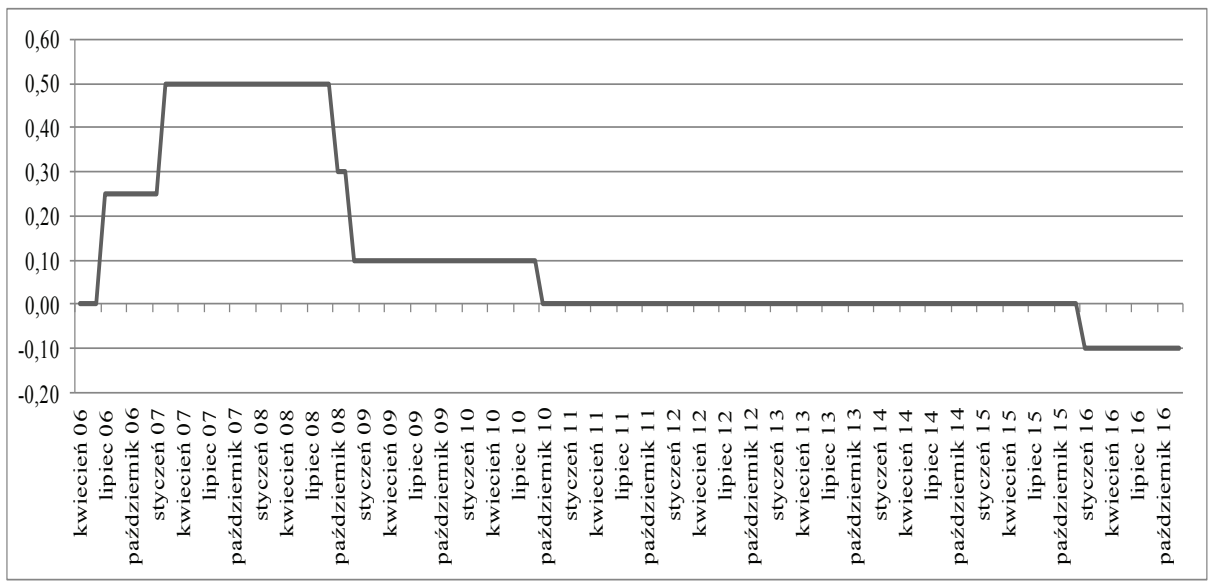

Ź r ó dło: opracowanie własne na podstawie danych Banku Japonii.

\section{Polityka monetarna Banku Japonii w latach 2008-2016}

Silne zaburzenia na międzynarodowych rynkach finansowych po roku 2007 spowodowały, że Bank Japonii, kierując się swym dotychczasowym nastawieniem polityki monetarnej lat 2001-2006, powrócił do jej niestandardowych instrumentów. W roku 2008 zwiększył zakres operacji otwartego rynku (poszerzając zakres instrumentów akceptowanych jako zabezpieczenie i stopniowo zwiększając wartość operacji). Tymczasowo wprowadził nowe typy operacji (np. bezwarunkowy skup krótko- i długoterminowych korporacyjnych papierów dłużnych). Z uwagi na zakończenie niektórych programów skupu papierów wartościowych w $2008 \mathrm{r}$. ogłosił nowy Program Skupu Aktywów (Asset Purchase Programme-APP) - japońskich obligacji i bonów skarbowych, dłużnych papierów korporacyjnych, jednostek ETF (exchange-traded funds) oraz jednostek funduszy inwestycyjnych rynku nieruchomości (REITS). W ramach tego programu przeprowadzał dodatkowo operacje o stałym oprocentowaniu zasilające sektor bankowy w płynność. Wartość skupowanych aktywów oraz udzielanych pożyczek w ramach APP była wielokrotnie zwiększana, z 35 bln jenów w październiku 2010 r. do 65 bln jenów w lutym 2012 r. W październiku 2010 r. BJ powrócił także do polityki zerowych stóp procentowych. 
Utrzymujący się w gospodarce Japonii niski wzrost gospodarczy, spowodowany w znacznym stopniu globalną recesją zwiększył też zaangażowanie nowego premiera Shinco Abe w zakończenie niemalże 20-letniego okresu przedłużającej się deflacji. Przygotowany został rządowy program oparty na tzw. polityce trzech strzałek (abekonomia), czyli polityce pieniężnej, fiskalnej oraz polityce strukturalnych reform odrzucający wszelkie restrykcje w kształtowaniu podaży jena w gospodarce. Założeniem programu gospodarczego Japonii stało się dalsze zwiększenie wydatków publicznych w kraju, w którym według MFW dług publiczny w stosunku do PKB wynosi ok. 236\% (jest to najwyższy na świecie dług publiczny). Towarzyszy temu prowadzona przez Bank Japonii luźna polityka pieniężna, oparta na comiesięcznym skupie z rynku obligacji skarbowych o wartości 80 mld dolarów. Osiagnięcie wzrostu inflacji mają zapewnić Japonii także zakupy innych nieskarbowych aktywów finansowych przez BoJ. Od stycznia 2014 r. skupować on może każdego miesiąca takie aktywa o wartości 13 bln jenów, czyli około 145 mld dolarów, przy czym skala zakupów jest nielimitowana.

W lutym 2012 r. Rada Polityki (Policy Board) Banku Japonii wprowadziła cel stabilności cen (price stability goal) w średnim i długim okresie definiowany jako inflacja mierzona wskaźnikiem CPI nieprzekraczająca 2\%. Przyjęła jednak, że tymczasowo wynosić on będzie 1\%. Oznacza to kontynuację ekspansywnej polityki monetarnej Banku Japonii, której dotychczasowe efekty nie spowodowały osiagnięcia celu inflacyjnego.

Niska skuteczność nadzwyczajnej polityki monetarnej BoJ w zwiększeniu inflacji w Japonii do zakładanego 2\% poziomu przyczyniła się do tego, że Bank of Japan ogłosił więc plan podwojenia podaży pieniądza. W nowej odsłonie nadzwyczajnej polityki monetarnej zapowiada nową fazę luzowania monetarnego - zarówno w kategoriach ilościowych, jak i jakościowych tak, aby radykalnie zmienić oczekiwania rynków i podmiotów gospodarczych. BoJ zapowiada zwiększanie bazy monetarnej o 60-70 bln JPY (637-744 mld USD), czyli ilości pieniądza w obiegu i w rezerwach bankowych. Pod koniec 2012 r. baza ta wynosiła 138 bln JPY (1,45 bln USD).

Decyzja BoJ niewątpliwie jest efektem nacisków ze strony premiera Shinzo Abe, który domaga się ,agresywnego luzowania monetarnego”, co wywołuje dyskusję o niezależności polityki monetarnej tej instytucji monetarnej.

Charakterystyczne natomiast jest to, że chociaż Prezes Banku Japonii, Haruhiko Kuroda, poinformował o utrzymaniu dotychczasowych założeń prowadzonej polityki monetarnej, BoJ nie zdecydował się na kolejną obniżkę ujemnej stopy depozytowej. 


\section{Zakończenie}

Doświadczenia Japonii z lat 2001-2007 pokazują, że wyjście z nadzwyczajnej polityki monetarnej quantitative easing jest możliwe w sposób płynny (wykres 6).

WYKRES 6: Zmiany realnego PKB, inflacji oraz akcji kredytowej w Japonii w latach 2000-2007

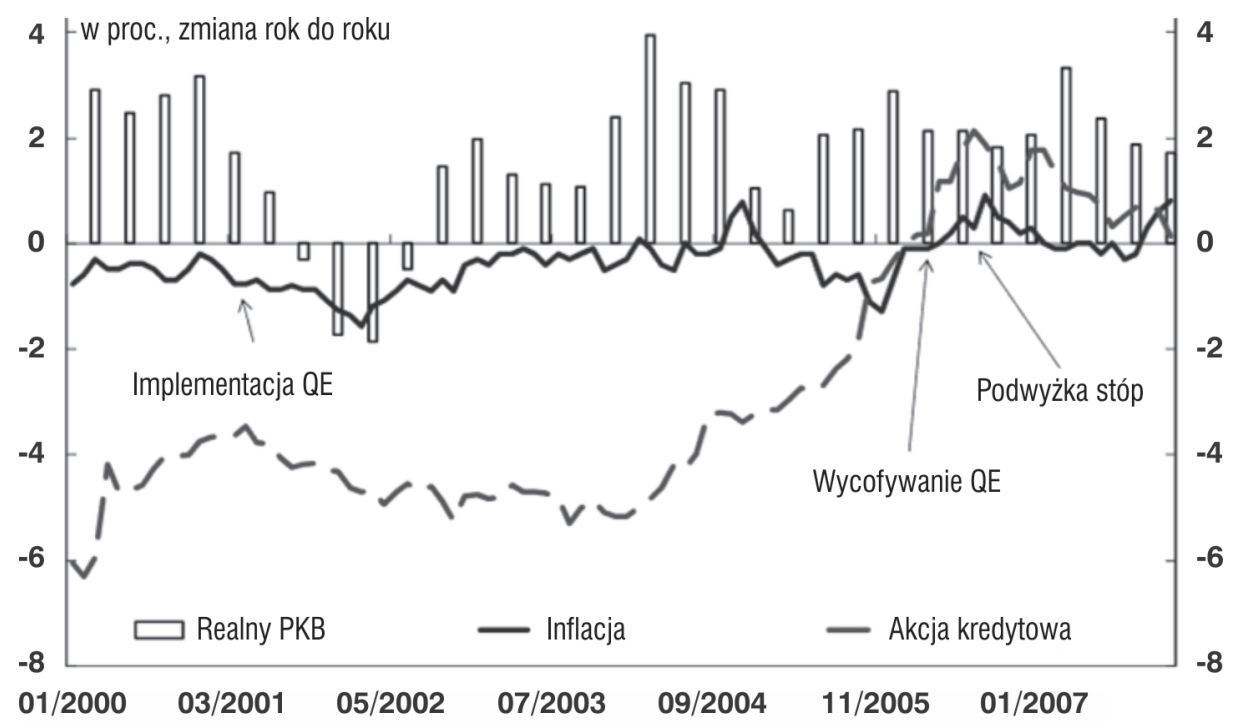

Ź r ó dł o: H. Yamaoka, M. Syed, Managing the Exit: Lessons from Japan’s Reversal of Unconventional Monetary Policy, IMF Working Paper, WP/10/114, May 2010, s. 10.

Wraz z oficjalnym zakończeniem luzowania ilościowego w roku 2006, Bank Japonii z powodzeniem zmniejszył swój bilans i nadwyżki rezerw bankowych w ciagu zaledwie kilku miesięcy. Strategia wyjścia BoJ nie spowodowała też żadnych widocznych zakłóceń na rynkach finansowych. Nie odnotowano gwałtownych zmian struktury portfela lub zwiększonej zmienności zarówno zabezpieczonych, jak i niezabezpieczonych aktywów finansowych. Stopniowa i uporządkowana realizacja exit strategy w zakresie posiadanych przez BoJ skarbowych papierów wartościowych przyczyniła się natomiast do wzrostu ich rentowności o 35 punktów bazowych. Pomimo znacznej skali luzowania ilościowego bank centralny Japonii nie wyzwolił jednak w gospodarce silnej presji inflacyjnej.

Doświadczenia Banku Japonii wskazują natomiast, że strategie wyjścia wymagają uporządkowania działań normalizujących politykę monetarną w zakresie: 
1. Dyscypliny w realizacji bezwarunkowych programów zakupu rządowych papierów wartościowych. Bank Japonii ustanowił reguły nabywania instrumentów skarbowych (tzw. banknote rule). Łączna wartość długoterminowych papierów wartościowych emitowanych przez Skarb Państwa nie mogła przekraczać wielkości pieniądza znajdującego się w obiegu, co miało na celu utrzymanie samodyscypliny zakupów dokonywanych w ramach polityki luzowania ilościowego.

2. Sposobu realizacji standardowych operacji otwartego rynku w okresie nadzwyczajnej polityki monetarnej.

3. Kształtowania struktury aktywów i pasywów bilansu i budowania strategii nabywania skarbowych papierów wartościowych - bonów i obligacji19.

4. Przygotowania i przyjęcią szczegółowych wytycznych dotyczących sprzedaży posiadanych papierów wartościowych (tzw. selling guidelines ). W lipcu 2007 r. na etapie realizacji strategii wyjścia Bank Japonii powierzył sprzedaż instrumentów bankom powierniczym, różnicując terminy ich sprzedaży, tak by zminimalizować wpływ wyprzedaży papierów wartościowych na rynki kapitałowe.

5. Wykorzystania komunikacji z uczestnikami rynku ${ }^{20}$.

6. Kontroli realizacji celu inflacyjnego.

Doświadczenia BoJ powstałe w okresie globalnego kryzysu finansowego pokazały dodatkowo, że exit strategy musi też być zorientowana na przyszłość. Ważnąjest ocena makroekonomicznych warunków rozwoju gospodarki w zakresie wzrostu gospodarczego oraz poziomu cen w horyzoncie rocznym lub 2-letnim, jak też długookresowa analiza różnych rodzajów ryzyka, takich jak narastanie bańki cen aktywów czy nadmierna akcja kredytowa, które mogą oddziaływać na ceny bądź też sferę realnej gospodarki.

W strategii wyjścia z nadzwyczajnej polityki monetarnej Banku Japonii ważną okazała się również minimalizacja wpływu jego wycofywania się z nabytych uprzednio akcji. Instrumenty udziałowe nie mają bowiem terminu zapadalności, a ich pozostawanie w bilansie banku centralnego może generować wysokie ryzyko finansowe. Dlatego też BoJ już na etapie wdrażania nadzwyczajnych programów (tzw. enter strategy) określił maksymalną kwotę przeznaczoną na zakup akcji do 3 bln JPY. Ponadto ograniczył kwalifikowalność tych instrumentów będących w posiadaniu banków do takich, których pakiety akcji przekraczały wartość współczynnika Tier I, jak również wdrożył w nich „klauzulę wygaśnięcia”.

9 H. Yamaoka, M. Syed, op. cit., s. 8.

20 S. Kozicki, E. Santor, L. Suchanek, Unconventional Monetary Policy: The International Experience with Central Bank Asset Purchases, Bank of Canada Review, Spring 2011, s. 21. 
Doświadczenia BoJ pozwalają też na wskazanie ogólnych zasad ważnych $\mathrm{w}$ realizacji exit strategy. Dotyczą one ${ }^{21}$ :

1) sposobu wykorzystania narzędzi w procesie wycofywania się z niestandardowej polityki pieniężnej,

2) cech pakietu nadzwyczajnych instrumentów niestandardowej polityki monetarnej,

3) sposobu komunikacji banku centralnego z rynkami finansowymi,

4) sformułowanego programu normalizacji polityki monetarnej.

Pokazują też, że nadzwyczajna polityka monetarna może mieć długotrwały i powtarzalny charakter, a jej skuteczność okazać się niska, podobnie jak strategie powrotu do normalizacji polityki monetarnej.

\section{Bibliografia}

\section{Opracowania}

Bank of Japan, Money market operations in Fiscal 2003, Financial Markets Department, August 2004.

Bank of Japan, Money market operations in Fiscal 2006, Financial Markets Department, July 2007.

Berkmen S. Pelin, Bank of Japan's Quantitative and Credit Easing: Are They Nom More Effective, IMF Working Paper 2012, WP/12/2, Washington.

Blinder Alan S., Quantitative Easing: Entrance and Exit Strategies, Federal Reserve Bank of St. Louis Review, November/December 2010/92 (6).

Financial Stability Board, Exit from extraordinary financial sector support measures, Note for G20 Ministers and Governors meeting 6-7 November 2009.

Goldman Sachs, BoJ terminates quantitative easing policy: Nominal tightening, but real easing, Japan Economic Flash, 9 March 2006.

Goldman Sachs, Quantitative Easing: The final chapter, Japan Economics Analyst, 3 March 2006.

Jyske Bank, Monetary Policy - Exit Strategy, Macroeconomic Research Jyske Markets, 23 March 2010.

Kozicki Sharon, Santor Eric, Suchanek Lena, Unconventional Monetary Policy: The International Experience with Central Bank Asset Purchases, Bank of Canada Review, Spring 2011.

Maeda Eiji, Fujiwara Bunya, Mineshima Aiko, Taniguchi Ken, Japan's open market operations under the Quantitative Easing policy, Bank of Japan Working Paper Series 2005/ 05-E-3.

Nishizaki Kenji, Sekine Toshitaka, Ueno Yoichi, Chronic Deflation in Japan, Bank of Japan Working Paper 2012/12-E-6, Bank of Japan, Tokyo.

Ugai Hiroshi, Effects of the Quantitative Easing Policy: A Survey of the Empirical Evidence, Bank of Japan Working Paper, July 2006/06-E-10.

${ }^{21}$ H. Yamaoka, M. Syed, op. cit., s. 12-13. 
Van Rixtel Adrian, The exit from Quantitative Easing (QE): The Japanese experience, w: Symposium Report, Armonk, New York, 23-25 October 2009 r.; http://www.law.harvard.edu/ programs/about/pifs/symposia/japan/2009-japan/final-report/2009-japan-u.s.-symposium-final-report.pdf; stan na 11.06.2015 r.

Yamaoka Hiromi, Syed Murtaza, Managing the Exit: Lessons from Japan's Reversal of Unconventional Monetary Policy, IMF Working Paper, May 2010/WP/10/114.

\title{
Strony internetowe
}

http://www.federalreserve.gov/monetarypolicy/files/fomcminutes20110622.pdf; stan na dzień 11.08.2014.

http://www.marketminder.com/a/fisher-investments-shinzo-abes-unstimulatingstimulus/7dbad7e4-4d0a-47bf-962c-714100ffc3e8.aspx; stan na dzień 16.06.2015.

Irena PYKA

Aleksandra NOCOŃ

\section{THE CONCEPT AND MAIN ASSUMPTIONS OF EXIT STRATEGY FROM THE PERSPECTIVE OF EXPERIENCE OF CENTRAL BANK OF JAPAN}

\author{
( Sum mary)
}

Exit strategy is a concept of exit of the global financial crisis, developed as a result of political will of G-20 countries, expressed in the documents of FSB (Financial Stability Board). It means a return to a "normal" monetary policy, so from the period before the global financial crisis. However, central banks which have implemented unconventional monetary policy can not exit from it, in spite of numerous declarations of its normalization. Unstable macroeconomic situation of Japanese economy after the global financial crisis caused an interest in terms of exit from unconventional monetary policy of Bank of Japan. The central bank has a significance experience both in its dissemination, as well as normalization. Just before the global financial crisis, Bank of Japan started the process of normalization its unconventional monetary policy, implemented in the 90s XX century, and again has faced the need to return to it. The case study analysis of Japanese central bank has caused that the main aim of the study is identification and verification of such characteristics of exit strategy concept, which implemented should increase the effectiveness and safety of monetary policy normalization of central banks after the global financial crisis.

The main objective of the study is identification and verification of characteristics of Bank of Japan exit strategy concept, aimed at increasing the efficiency and safety of the normalization process of monetary policy of central banks after the global financial crisis. The following research methods were used in the article: case study, observation analysis, cause and effect analysis, document analysis and synthesis analysis.

Keywords: exit strategy; Bank of Japan; quantitative easing; zero-bound interest rate policy; monetary policy normalization 